Shrub, Scrub, and Grass: The Importance of Shrubland and Grassland Plant Communities to the Diet of the Late Prehistoric (A.D. 900-1535) Hunter-Gatherers of the Eastern Trans-Pecos Region of Texas

Casey W. Riggs

Department of Anthropology, Texas A\&M University

Follow this and additional works at: https://scholarworks.sfasu.edu/ita

Part of the American Material Culture Commons, Archaeological Anthropology Commons, Environmental Studies Commons, Other American Studies Commons, Other Arts and Humanities Commons, Other History of Art, Architecture, and Archaeology Commons, and the United States History Commons

Tell us how this article helped you.

This Article is brought to you for free and open access by the Center for Regional Heritage Research at SFA ScholarWorks. It has been accepted for inclusion in Index of Texas Archaeology: Open Access Gray Literature from the Lone Star State by an authorized editor of SFA ScholarWorks. For more information, please contact cdsscholarworks@sfasu.edu. 


\section{Shrub, Scrub, and Grass: The Importance of Shrubland and Grassland Plant Communities to the Diet of the Late Prehistoric (A.D. 900-1535) Hunter-Gatherers of the Eastern Trans-Pecos Region of Texas}

\section{Licensing Statement}

Reproduction, posting, transmission, or other distribution or use of the Journal volume, individual article or any portion of the material therein, in any medium, is permitted strictly for personal, non-commercial purposes via a personal-use exemption under a Creative Commons license granted by JTAH.org, Inc. This license exemption requires, as a condition of its granted permission, proper credit be attributed to JTAH.org as copyright holder (e.g., Journal of Texas Archeology and History.org @ 2014). No part of this publication may be reproduced, posted, transmitted, or otherwise utilized or distributed in any form by any means or method for commercial purposes without the express written consent of the Publisher. Inquiries should be addressed to JTAH Publisher, Suite 307, Box 361, 5114 Balcones Woods Drive, Austin, Texas, 78759.

The Journal of Texas Archeology and History.org is an organization dedicated to furthering research, education and public outreach in the fields of archeology and history concerning Texas and its bordering states of Louisiana, Arkansas, Oklahoma, New Mexico and Northern Mexico; a region we call the "Texas Borderlands." The J.T.A.H. is collaborating with the Index of Texas Archaeology and S.F.A.S.U. to distribute their publication library to the general public via free and open-access channels. Visit www.JTAH.org to submit an article. 


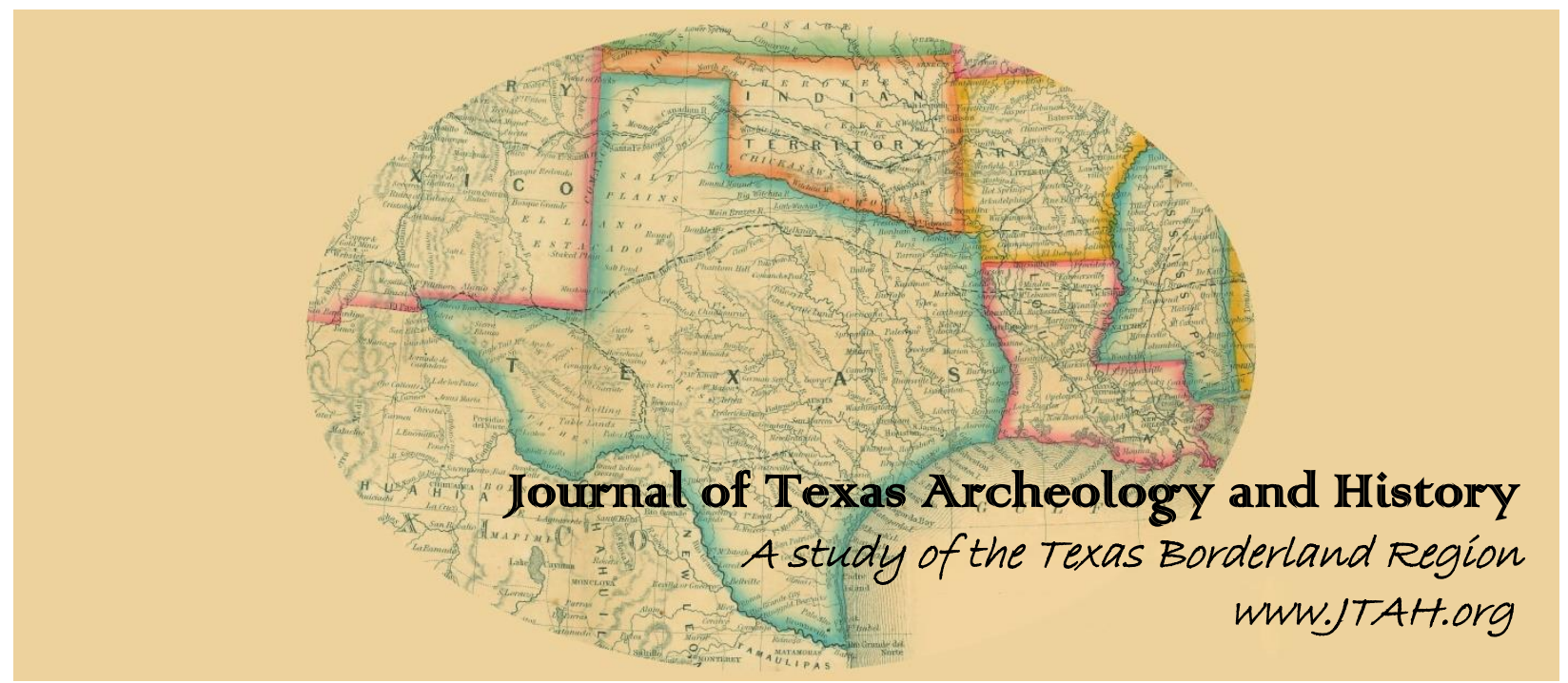

\section{Article Title: SHRUB, SCRUB, AND GRASS: THE IMPORTANCE OF SHRUBLAND AND GRASSLAND PLANT COMMUNITIES TO THE DIET OF THE LATE PREHISTORIC (A.D. 900-1535) HUNTER- GATHERERS OF THE EASTERN TRANS-PECOS REGION OF TEXAS \\ Author(s): $\quad$ Casey W. Riggs}

Original Source: J.T.A.H. Volume 1 (2014), Article 1, pp. 1 - 26; online 06 November 2014

Recommended Citation: Riggs, Casey W., "Shrub, Scrub, and Grass: The Importance of Shrubland and Grassland Plant Communities to the Diet of the Late Prehistoric (A.D. 900-1535) HunterGatherers of the Eastern Trans-Pecos Region of Texas", (2014), Journal of Texas Archeology and History Volume 1 (2014), pp. 1-26.

Copyright (C) 2014 by Journal of Texas Archeology and History.org, Inc. All rights reserved. Online/Digital publication: ISSN 2334-1874

The online, digital and print versions of the publication "Journal of Texas Archeology and History" are published by Journal of Texas Archeology and History.org, Inc., a Texas nonprofit IRC Section 501(c)(3) corporation.

Reproduction, posting, transmission, or other distribution or use of the Journal volume, individual article or any portion of the material therein, in any medium, is permitted strictly for personal, non-commercial purposes via a personal-use exemption under a Creative Commons license granted by JTAH.org, Inc. This license exemption requires, as a condition of its granted permission, proper credit be attributed to JTAH.org as copyright holder (e.g., Journal of Texas Archeology and History.org (C) 2014). No part of this publication may be reproduced, posted, transmitted, or otherwise utilized or distributed in any form by any means or method for commercial purposes without the express written consent of the Publisher. Inquiries should be addressed to JTAH Publisher, Suite 307, Box 361, 5114 Balcones Woods Drive, Austin, Texas, 78759

The Journal of Texas Archeology and History.org is an organization dedicated to furthering research, education and public outreach in the fields of archeology and history concerning Texas and its bordering states of Louisiana, Arkansas, Oklahoma, New Mexico and Northern Mexico; a region we call the "Texas Borderlands." The J.T.A.H. is collaborating with the Index of Texas Archaeology and S.F.A.S.U. to distribute their publication library to the general public via free and open-access channels. Visit www.JTAH.org to submit an article. 


\title{
SHRUB, SCRUB, AND GRASS: \\ THE IMPORTANCE OF SHRUBLAND AND GRASSLAND \\ PLANT COMMUNITIES TO THE DIET OF THE LATE \\ PREHISTORIC (A.D. 900-1535) HUNTER-GATHERERS \\ OF THE EASTERN TRANS-PECOS REGION OF TEXAS
}

Casey W. Riggs

\begin{abstract}
The Eastern Trans-Pecos archeological region of Texas is an area rich in botanical diversity, a resource heavily utilized by both prehistoric and historic hunter-gatherers. A comparison of four paleoethnobotanical investigations of archeological sites dating to the Late Prehistoric Era (A.D. 900-1535) with ethnobotanical information of the Mescalero Apache reveal that the botanical component of prehistoric and historic diets have been similar for the past 1,000 years. Differences in the degree of similarity can be contributed to differential preservation and analytical techniques. Further, ecological sites from the Ecological Site Information System are demonstrated as a novel and useful tool for landscape-scale archeological analysis.
\end{abstract}

\section{INTRODUCTION}

This study examines the use of locally available plant food species at four Late Prehistoric Era (A.D. 900-1535) hunter-gatherer and forager-farmer sites in the Eastern Trans-Pecos archaeological region of Texas (Figure 1). The overarching objective of this study is to understand how Late Prehistoric hunter-gatherers utilized local landscapes for the botanical portion of their diet, specifically the kinds of plants consumed, and not necessarily the importance of a given taxa nor the primary foods consumed, processed, or stored at a given archeological site. With such subsistence related data available future studies can be expanded to examine seasonal dietary variation as well as changes in subsistence patterns, logistical strategies, and socio-cultural identities through time.

To identify potential food resources of Late Prehistoric peoples in the Eastern Trans-Pecos this study compares archeologically encountered plant foods to the ethnographically described diet of the Mescalero Apache. This comparison is undertaken at a site specific level through data extraction from an ecological spatial model. Data for this model were generated in a geographic information system via the Ecological Site Description system developed by the United States Department of AgricultureNatural Resource Conservation Service (USDA-NRCS) in tandem with the United States Department

\footnotetext{
JOURNAL OF TEXAS ARCHEOLOGY AND HISTORY

VOLUME 1:1-26

THE ONLINE PUbliCATION JOURNAL OF TEXAS ARCHEOLOGY AND HISTORY (ISSN 2334-1874)

IS PUBLISHED BY JOURNAL OF TEXAS ARCHEOLOGY AND HISTORY.ORG. COPYRIGHT (c) 2014 JOURnAl OF TEXAS ARCHEOLOGY AND HistORY.ORG. AlL RIGHTS RESERVED.
} 


\section{Eastern Trans-Pecos Archaeological Region}

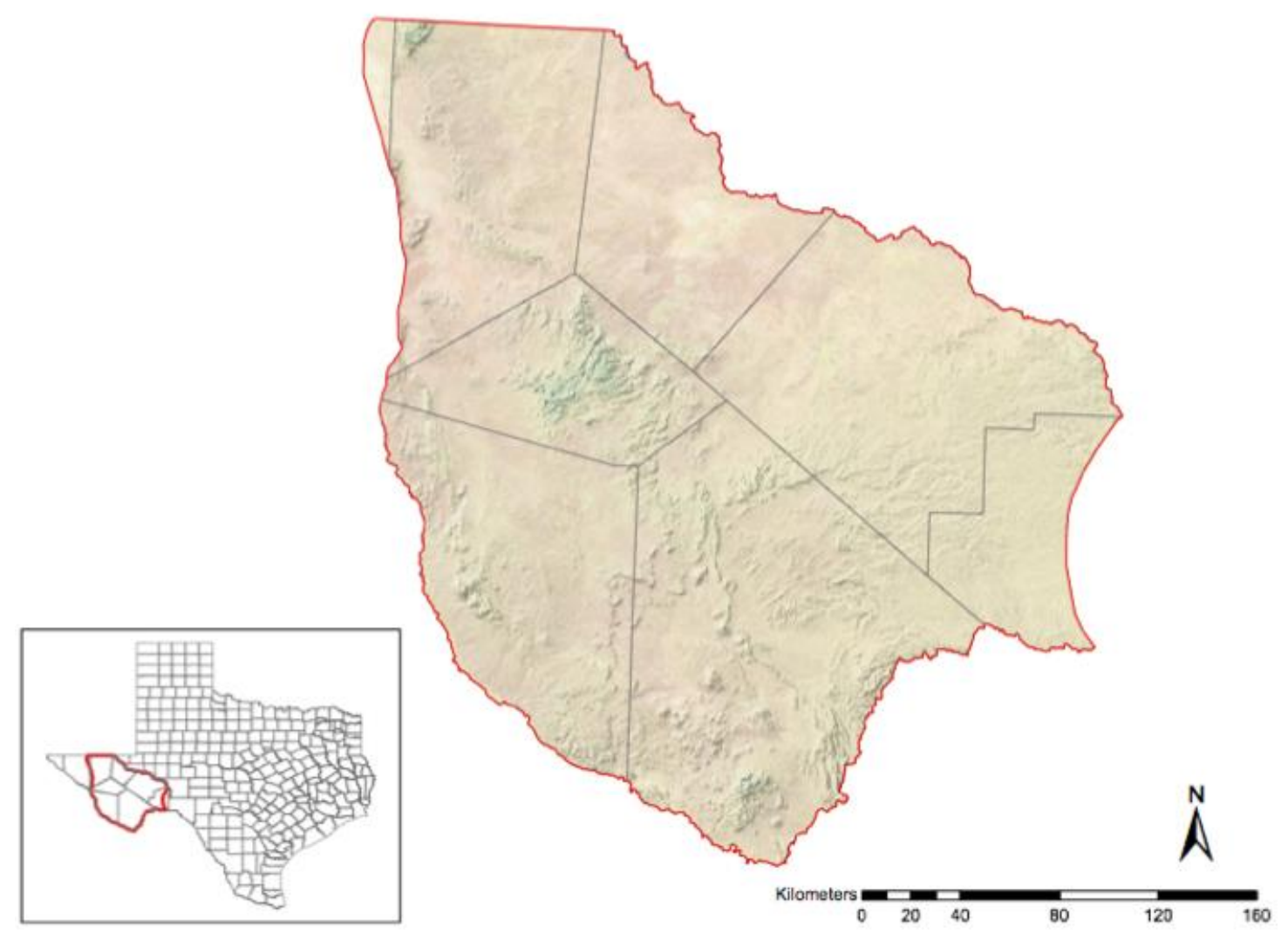

Figure 1. The study area.

of the Interior-Bureau of Land Management (BLM) and the USDA-Forest Service (USDA-NRCS et al. 2013).

The results demonstrate that there is a dramatic overlap between historic and prehistoric plant diet with only two ethnographically confirmed dietary outliers within the archeological record. Here a dietary outlier is considered plant taxa used for food by Late Prehistoric peoples but not by the Mescalero Apache. The Mescalero Apache show a more varied diet, although this discrepancy is likely the result of preservation bias as well as a lack of microbotanical analyses within the Eastern Trans-Pecos. Finally this project's utilization of a novel spatial ecological model, the USDA-NRCS Ecological Site Description system, for archeological inquiry demonstrates the utility of this model for related landscape level archeological investigations. 


\section{ECOLOGICAL AND ARCHEOLOGICAL BACKGROUND}

The Eastern Trans-Pecos archeological region (see Figure 1) constitutes a large portion of the northeastern Chihuahuan Desert eco-region, and as such is an arid to semi-arid area with a bimodal precipitation regime (Hoyt 2000; Pronatura Noreste et al. 2004). Climatically the study area has cool dry winters and warm dry summers, is prone to frequent and intense droughts, and is heavily influenced by the El Niño-La Niña Southern Oscillation system (Poulos 2007; Warnock 2010).

Paleoenvironmental studies have demonstrated that little natural ecological change has occurred from A.D. 900 to the present (Wells 1966; Hoyt 2000). However, Euro-American arrival, settlement, and landscape use caused dramatic ecological change, primarily by removing fire as a disturbance and through livestock overgrazing (Poulos 2007; Warnock 2010). Both of these occurrences led to the transition from grassland to shrubland communities in many areas. Despite this, 91 plant communities, predominantly grasslands and shrublands, lie within the bounds of the Eastern TransPecos according to USDA-NRCS plant community data. Higher elevation mountains support sky island ecosystems that are more pine (Pinus spp.) forest in nature, while the two rivers (Pecos River and Rio Grande) on the periphery of the study area, and several creeks, support a variety of tree species (Hatch et al. 1990; Powell 1994, 1998).

The Eastern Trans-Pecos is archeologically defined as the area lying south and west of the Pecos River, bordering the Lower Pecos region, north of the Rio Grande, west of Lobo Valley and the Great Salt Basin in Culberson County, and south of the Texas-New Mexico state border. Archeological remains demonstrate that this area was culturally distinct throughout prehistory, but more prominently so in the Late Prehistoric period. This is signaled by a lack of settlements, farming, and pottery production in comparison to the Western Trans-Pecos, with the exception of the La Junta District (Mallouf 1985; Miller and Kenmotsu 2004; Perttula 2004). In terms of distinguishing the Eastern Trans-Pecos from other archeological regions, the Southern Plains to the north of the study area show higher mobility and greater emphasis on bison (Bison bison) procurement (Perttula 2004). The Central Texas region to the east of the study area lacks the regionally specific Livermore, Diablo, Means, and Alazan arrow points and was dominated by the settlements of Austin phase and Toyah phase groups during the Late Prehistoric (Arnn 2012; Collins 2004; Johnson 1994; Mallouf 2012, 2013). Within the Lower Pecos to the southeast groups did not utilize the Livermore, Diablo, Means, and Alazan arrow points in their hunting equipment nor is the Cielo Complex present within the region (Mallouf 1985).

Within the Eastern Trans-Pecos the Late Prehistoric period is demarcated by the reliance on bow and arrow hunting technology with diagnostic arrow point types including Livermore, Toyah, Perdiz, and Fresno (see Turner et al. [2011] for a discussion of these types) as well as the recently defined Diablo, Means and Alazan types (see Mallouf [2012, 2013] for discussion of their morphological attributes). Pottery was minimally utilized throughout this era, with wares of local (created within the La Junta District) and exotic origin (originating from northern Mexico, the Western Trans-Pecos, central and southern New Mexico, and far East Texas) (Cloud 2004; Cloud et al. 2004; Kenmotsu 2013). Most pottery artifacts are encountered on sites in the La Junta District and the Pecos River valley (Mallouf 1985). Although horticulture occurred in the region, it was solely within the La Junta 
District; cultigens are not examined in this study, as it focuses specifically on Late Prehistoric era hunter-gatherers and their collecting practices. Additionally, two primary archeological huntergatherer groups have been identified in the archeological record: the Livermore phase and the Cielo Complex.

\section{Livermore Phase}

Defined by Kelley et al. (1940) and revised by Kelley (1957), the Livermore phase (ca. A.D. $900-$ 1300 ) is typified by nomadic hunter- gatherers who utilized bow and arrow hunting technology and occupied the area between southeastern New Mexico and northeastern Chihuahua. At this time the Livermore phase remains poorly defined, although elements of mountain-top ritualism and material culture remains are known (Seebach 2007). Projectile points typically found in association with one another include the Livermore, Toyah, and Fresno (Mallouf 1999) as well as Diablo, Means, and Alazan (Mallouf 2012). Mountain-top ritualism is noted because of the presence of two large arrow point caches, the Livermore and Means caches, atop two mountainous peaks in the study area (Mallouf 2009). Kelley (1957) posits that the Livermore phase indicates an incursion of Plains-based hunter-gatherers, while Mallouf (1999) cautions that the archeological culture it represents may be that of an indigenous group.

\section{Cielo Complex}

Another hunter-gatherer group in the study area, the Cielo Complex (ca. A.D. 1250-1680) represents a unique archeological complex identified by Mallouf (1985). Classic Cielo Complex sites have stacked stone-based wickiup structures atop readily defendable locations at both long term and short term locales (Mallouf 1999). Cielo Complex groups predominately utilized the Perdiz arrow point, but Garza and Soto points become more common later in prehistory (Mallouf 1999). Other chipped stone tool types include blades, blade drills, formal end scrapers, beveled knives, and prismatic blade cores. These chipped stone tools are also diagnostic of the Toyah phase of Central Texas (Johnson 1994), although a key difference between these two archeological groups is the absence of pottery at Cielo Complex sites. Mallouf (1999) suggests the Cielo Complex may be ancestral to the Protohistoric and Historic era Jumano, while Mallouf also hypothesizes that this archeological complex could be the remains of one or more indigenous groups in the region.

Relying on Spanish accounts it is understood that the majority of the Eastern Trans-Pecos inhabitants were hunter-gatherers during the Protohistoric period (A.D. 1535-1700) (Cloud 2004; Mallouf 1999; Miller and Kenmotsu 2004). The primary hunter-gatherer groups mentioned include the Jumano, Chisos, and Gediondo, while the La Junta District farmers are described primarily as the Patarbueye (Arnn 2012; Kelley 1986; Kenmotsu 1994; Kenmotsu and Wade 2002). Later, during the Historic Era (A.D. 1700-Present) these indigenous groups were replaced by Athabascan speakers (i.e., Mescalero Apache), later by settlers from Spain and Mexico, and finally Euro-Americans. All of these

groups, whether Late Prehistoric, Protohistoric, or Historic/modern, have had a direct relationship with the biotic communities present within the Eastern Trans-Pecos. Although these relationships are obviously different (e.g., modern groups do not rely on foraging for subsistence as the Chisos hunter- 
gatherers would have), this harsh landscape undoubtedly left major impressions on these groups. With the understanding that all cultural groups have some sort of relationship with the landscape they inhabit, this study utilizes for the examination of biotic community relationships a spatial ecological proxy currently used by modern entities within the Eastern Trans-Pecos for natural resource management.

\section{Plant Communities, Ecological Stable State Theory, and Archeology}

Originally named the Soil Erosion Service, today's USDA-NRCS serves as a technical and financial assistance organization to help landowners in the United States maintain healthy landscapes (USDA-NRCS 2013). In this capacity the NRCS coordinated with the Bureau of Land Management and the U.S. Forest Service to create an interagency, standardized classification system of rangeland types to better monitor, inventory, evaluate, and manage the United States' rangelands (USDA-NRCS et al. 2013). This classification system, known as ecological site descriptions (ESD), is based upon soil characteristics, temperature and precipitation data, and topographic characteristics (e.g., slope and aspect), and plant community descriptions that define plant assemblages and disturbances that typify specific plant communities. These plant community descriptions provide taxa lists that typify the community as well as the percentages of the different taxa within the different communities (USDANRCS et al. 2013).

The ESD system is based on ecological stable state theory, wherein an ecosystem can experience a variety of stable states depending largely upon incipient ecological disturbance regimes (Beisner et al. 2003; Holling 1973; Law and Morton 1993). Once these disturbance regimes are altered (e.g., an increase or decrease in fire frequency, livestock overgrazing, global climate change, etc.) beyond a certain point the ecosystem then enters a transitional state. Upon entering its transition the ecosystem can revert to the previous stable state, if the original disturbance regime returns, or enter a different stable state (USDA-NRCS et al. 2013). It should be noted that this system only applies to small scale changes and not to more massive ecological transitions such as occurred in the Pleistocene-Holocene transition. However, the introduction of Old World plant taxa to the Americas is demonstrated in ecological sites as transitions away from the historic climax plant community.

Another key component to the ESD system is that the distinct plant communities can remain stable for extended periods of time (USDA et al. 2013), making them useful for archeological inquiry. Additionally, the entities involved with implementing the ESD system rely heavily upon paleoenvironmental data, historic accounts, and historic ecological data, as well as reference communities that possess little anthropogenic alteration since Euro-American settlement to define historic plant communities (USDA-NRCS et al. 2013). This, combined with studies demonstrating negligible environmental and climatic change since A.D. 900 within the Eastern Trans-Pecos (Davis 1989; Elias and Van Devender 1992; Hoyt 2000; Van Devender 1990), makes this system well suited as a spatial model for determining the availability of resources to Late Prehistoric era inhabitants within the study area. At this point the ESD system has not been fully completed for the study areaspecifically that the species composition data for the historic climax plant community have not been determined - but the spatial extent of 70 ecological sites is currently available. This is unsurprising 
given the amount of data required to delineate and describe ecological sites and that the system classification was initiated only 17 years ago (USDA-NRCS 2007). How this shortcoming was dealt with analytically is described in later portions of this article.

\section{METHODS}

To determine how hunter-gatherer peoples in the Eastern Trans-Pecos utilized the landscape around them for botanical food resources, four archeological sites are examined from the study area: Arroyo de la Presa Site (41PS800) (Cloud 2004), Tres Metates Rockshelter (41PS915) (Seebach 2007), Granado Cave (41CU8) (Hamilton 2001), and 41PC502 (Antiquities Planning and Consulting 2002) (Figure 2). These archeological sites were included because they were the only available data sources at the time of analysis. Data from these reports are then compared to the available native botanical dietary resources of the Mescalero Apache via data extraction from a spatial model (ESD system) in a GIS. Implications of the incomplete ESD System are quantified as is the degree of botanical taxa diversity within each site catchment area. Finally, a series of queries and comparisons are undertaken to best understand (a) the applicability of historic group diet to prehistoric group diet as well as (b) determining the applicability of ESD historic climax plant community descriptions within archeological methodological frameworks.

\section{The Late Prehistoric Eastern Trans-Pecos Botanical Diet Record}

The Arroyo de la Presa site (41PS800) is a multi-component open campsite in southeastern

Presidio County, located very close to the Rio Grande. Approximately $84 \mathrm{~m}^{3}$ of the deposits were excavated via 19 hand excavated units and four backhoe trenches. Eight stratigraphic zones were encountered with occupations in Zone IV beginning around A.D. 700 and occupation continued sporadically through A.D. 1260, dating this site primarily to the Late Prehistoric period. Twentyseven radiocarbon dates were obtained to date this zone. Investigations indicate that the Arroyo de la Presa site was predominantly a plant processing location based on feature types and macrobotanical analyses of feature contents. The recovery of faunal remains, combined with chemical analyses, demonstrated that terrestrial mammals and lotic (i.e., moving freshwater) resources were also processed at this location. Specific for this analysis, 33 matrix samples were analyzed for macrobotanical remains from 12 features: three stone hearths, five pits, two fire-cracked rock (FCR) concentrations within pits, a pavement of FCR, and a ring midden (Cloud 2004).

Tres Metates Rockshelter (41PS915) is located in southwestern Presidio County and was used first around A.D. 1200 and then again between A.D. 1440 and 1640, all during the Late Prehistoric. The presence of Toyah, Garza, and Livermore arrow points, a Perdiz arrow point preform, a Jornada Mogollon or Casas Grandes brownware sherd, a Carretas polychrome sherd, and two radiocarbon dates (750 \pm 60 B.P. and $360 \pm 40$ B.P.) from six excavation units demonstrate that there were two occupations at the site. Evidence from a plant-lined storage pit demonstrate that the rockshelter was primarily used as a locale for plant food gathering, processing, and storage (Seebach 2007). Seebach (2007) also postulates that this site was utilized by La Junta District forager-farmers to gather local plant species before transporting them back to villages along the Rio Grande and Rio Conchos. 


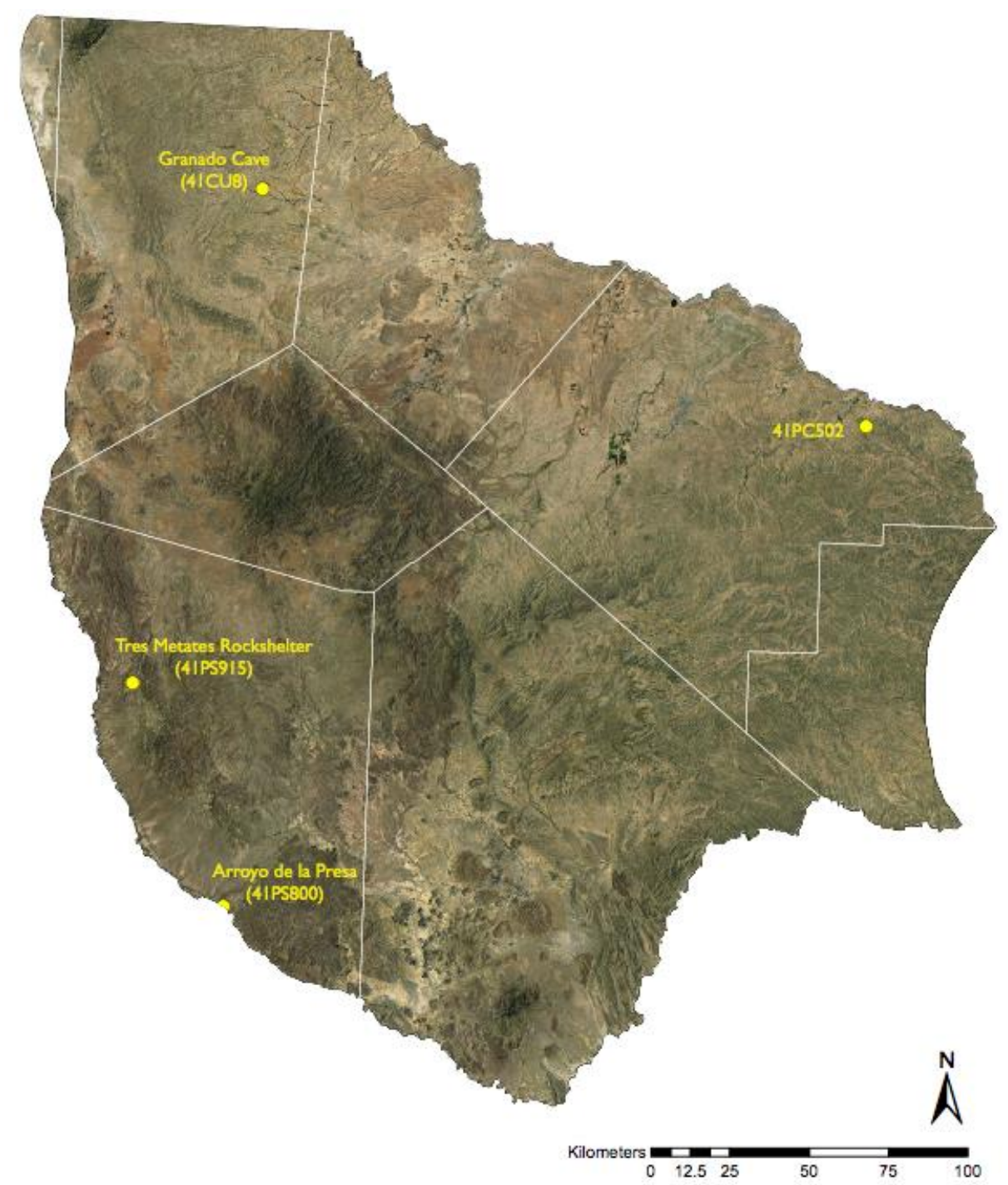

Figure 2. Map of archeological sites in the study area.

Granado Cave (41CU8), a sinkhole cave in eastern Culberson County, was occupied between A.D. 200 and A.D. 1450 based on 20 radiocarbon dates. Time diagnostic artifacts include five arrow points (one of which is a Livermore), and five pottery types: Matta Red-on-Brown, Chupadero Blackon-White, Convento Vertical Corrugated, Chihuahuan Brownware, and Jornada Brownware. The cave was used for habitation, food processing, and as a burial place based upon the variety of recovered artifacts and identified features. Botanical food sources were identified through pollen analysis of 16 human coprolites, one colon sample, and 10 sediment samples from human burials. These analyses indicate that the original inhabitants made full use of the limited faunal and many botanical resources of the surrounding landscape (Hamilton 2001).

41PC502, an open air campsite in eastern Pecos County on the Stockton Plateau, proved to be a multi-component site occupied during the Late Prehistoric. Eight radiocarbon dates were gathered from a hot rock oven facility and indicated that site use dated from A.D. 900 to A.D. 1430. Within this time frame the facility was used four times as a oven for processing members with side scrapers of 
the Agavaceae family. A crescent midden and hot rock baking pit (Feature 3) received the most attention during the excavations. Ten flotation and three macrobotanical samples were analyzed for macrobotanical remains (Antiquities Planning and Consulting 2002).

\section{Ethnographic and Ethnohistoric Comparisons}

To determine the degree to which Late Prehistoric groups utilized available plant species as food resources, the recorded diet of the historic Mescalero Apache is used for comparative analysis. This group was selected because the Mescalero Apache are historically known to be hunter-gatherers (Basehart 1960; Castetter and Bell 1936); the tribal group occupied the Chihuahuan Desert (Basehart 1960; Castetter and Bell 1936); there is ethnohistoric and archeological evidence for the displacement, absorption, or both, of peoples by Apache groups already occupying the Eastern Trans-Pecos (Mallouf 1999; Miller and Kenmotsu 2004; Seymour 2004); and ethnographic studies are available that provide extensive botanical diet information (i.e., Basehart 1960; Castetter and Opler 1936).

The Mescalero Apache had occupied virtually all of the study area by ca. A.D. 1500 based on ethnohistoric information and historic accounts (Arnn 2012; Hickerson 1994; Kelley 1986,;Kenmotsu and Arnn 2012). Additionally, archeological information from the Cielo Bravo site indicates that possible Athabascan speakers not only used the same site, but also occupied the same habitation features, as previous residents had done (see Mallouf [1999] for further discussion). This cultural absorption provides a unique grounds for dietary acculturation, this being a dynamic and complex phenomenon that can result in mixing of food ways by both cultural entities, wherein the immigrating group (i.e., the Mescalero Apache) adopts foods of the host, incipient group(s) (Satia-Abouta 2003). The extent of food way adoption is regulated by many factors such as religion, cultural beliefs and attitudes, as well as personal taste, texture, and color preferences (Satia-Abouta 2003). Hypothetically, dietary acculturation could have taken place in the Eastern Trans-Pecos by means of cultural contact or absorption. Examination of the literature indicate that dietary acculturation processes have never been examined in an archeological context but are increasing in number in applied anthropology situations to better understand processes of globalization (e.g., Kim et al. 2007; Regev-Tobias et al. 2012).

From an environmental deterministic perspective all Apachean groups would have needed to alter their diet to accommodate their adoption and use of resources in newly entered regions. The Mescalero Apache and other Athabascan speakers originated far to the north of the study area (Seymour 2012). Although two routes for ancestral Apachean migrations have been proposed (mountain [Seymour 2012] or plains [Wilcox 1981] routes), the Chihuahuan Desert is vastly different ecologically than any area Athabascan speakers originated from or moved through. If the newly arrived Apachean groups had not adapted their diet to the new environment, their likelihood of survival would have been greatly diminished.

Regardless of whether food adoption occurred as a result of cultural absorption/dietary acculturation, environmental adaptation, or a combination of the two, it should be reiterated that a primary purpose of this study is only to identify the similarity between the prehistoric and Mescalero 
Apache use of dietary species. No attempt was made to identify aspects of cultural change or conditions for the adoption of practices from the host group(s). Future studies should be concerned with establishing the reasons for this dietary similarity as it may relate to dietary acculturation in order to better understand the cultural changes Apachean groups underwent after arriving in the American Southwest and Texas.

To determine how similar Late Prehistoric and Historic era native plant diet are, an examination of the ethnographic literature is needed. Castetter and Opler's exemplary study of plant use by Mescalero and Chiricahua Apache was undertaken from 1931-1934. During this three year period a variety of data was gathered from ethnographic fieldwork on the Mescalero Reservation in south central New Mexico that was concerned with the botanical characteristics of Chiricahua and Mescalero Apache cultures (Castetter and Opler 1936). That being said, some aspects of material culture, linguistics, hunting, religion, and social organization were also discussed. Most importantly for this study, 70 different plant taxa were identified for food use, and information was gathered as well concerning their preparation strategies. As such, Castetter and Opler's study provides the greatest amount of ethnographic information specific to plant diet compared to a second Mescalero Apache ethnobiological study by Basehart (1960).

In contrast to the work completed by Castetter and Opler (1936), the study by Basehart (1960) was undertaken primarily to better understand the subsistence patterns and political organization of the Mescalero Apache. Interviews and field work were undertaken on the Mescalero Reservation from 1957-1960. I am most concerned with the subsistence patterns described by Basehart (1960), because while Basehart did not identify as many plant taxa as Castetter and Opler (1936), he did identify the staples of native plant diet as well as seasonal movements to procure these resources.

When taken together these two data sources indicate 70 different native plant taxa constituted the plant-heavy diet of the Mescalero Apache (Castetter and Opler 1936). Seasonally, this group relied heavily upon three taxa: agave (Agave spp.), prickly pear (Opuntia spp.), and datil yucca (Yucca baccata) (Basehart 1960). Small seeds from grasses, berries, greens, piñon (e.g., Pinus edulis) nuts, oak (Quercus spp.) acorns, and the starchy bases of hydrophytic plants (e.g., cattail [Typha spp.]) were important portions of the native plant diet depending upon the season (see Castetter and Opler [1936] and Basehart [1960] for more detailed information).

\section{Spatial Data Extraction}

The exploitation of a plant community for native plant food resources from an archeological context is gained through knowledge of both plant communities and paleoethnobotanical remains, as well as comparisons with ethnographically described cultures of the same or similar geographic areas. To collect this knowledge, spatial and comparative analyses were undertaken to determine locally available dietary plant species use in hunter-gatherer and forager-farmer diets.

To identify what plant species were available, county level USDA-NRCS spatial data was downloaded from the "Web Soil Survey for Brewster, Culberson, Hudspeth, Jeff Davis, Pecos, Presidio, Reeves, and Terrell Counties in Texas." These data were incorporated into a Microsoft 
Access Database, and the ecological site names and their plotted extent was loaded in an ESRI ArcGIS 10.0 blank ArcMap document using the SoilViewer PlugIn 6.1.

Because only portions of Hudspeth, Jeff Davis, Presidio, and Terrell counties are within the Eastern Trans-Pecos archeological region, a georeferenced regional map from Cloud and Piehl (2008) was outlined and the counties clipped to the study area. Site locations for Arroyo de la Presa, Tres Metates Rockshelter, Granado Cave, and 41PC502 were then gathered from the Texas Archeological Site Atlas and plotted on the ecological site map for the area.

Ethnographic information has generally concluded that the maximum one day catchment for individuals gathering plant resources is 15 kilometers $(\mathrm{km})$ (Kelly 1995). Although the foraging radius from these sites may be smaller, by utilizing the maximum distance all possible variation in the distribution of plant resources is incorporated into the analysis. For the spatial analysis a $15 \mathrm{~km}$ buffer was generated around each site location and a union performed between the reconstructed foraging radii and the ecological site names layers (Figures 3 and 4). It should be noted that this analysis does not account for the consequences of terrain variability and labor expenditure in gathering plant resources but instead seeks to analyze the maximum possible ecological variability that occurs around these specific archaeological sites.

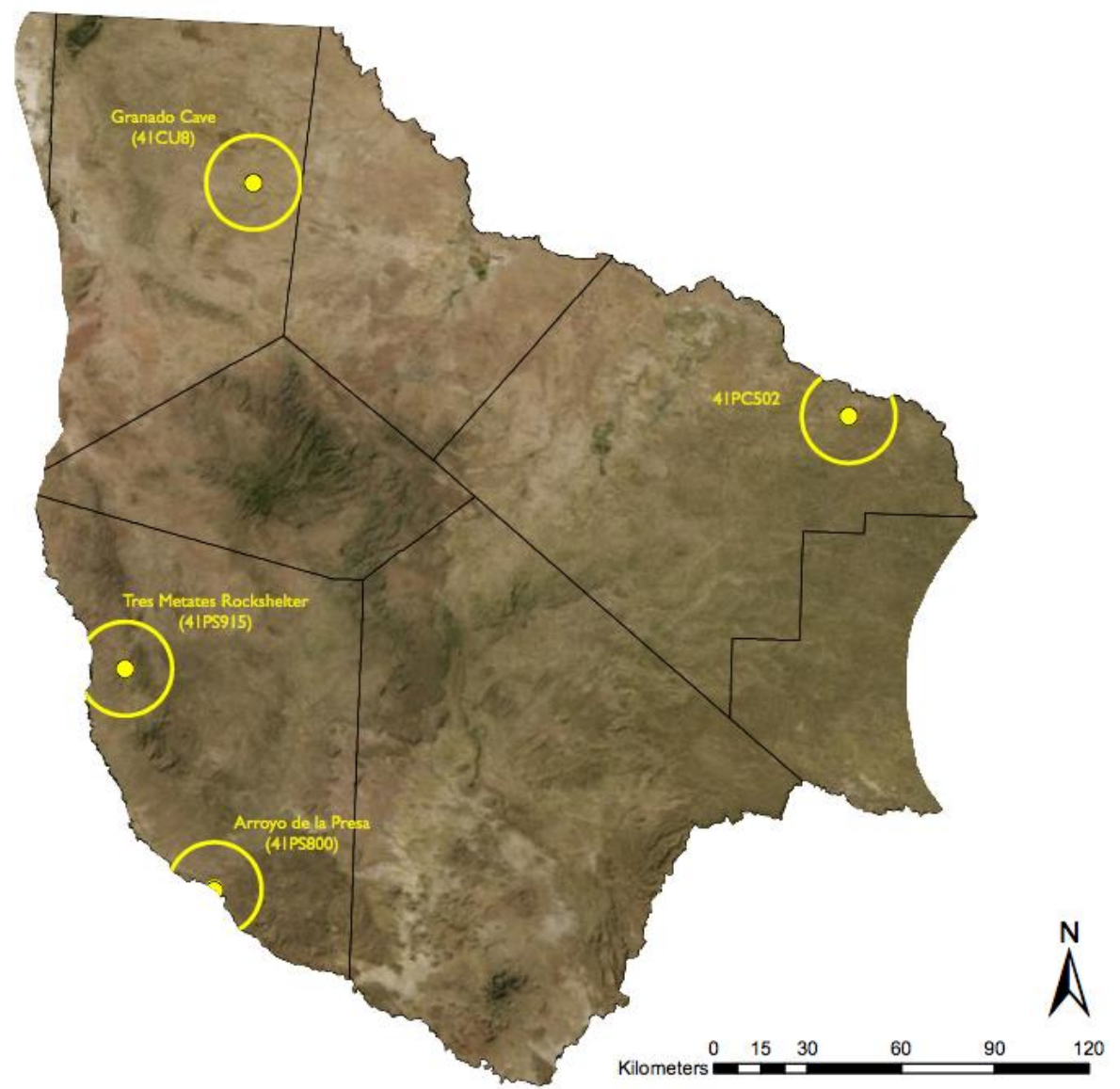

Figure 3. Reconstructed foraging radii of archeological sites in this study. 


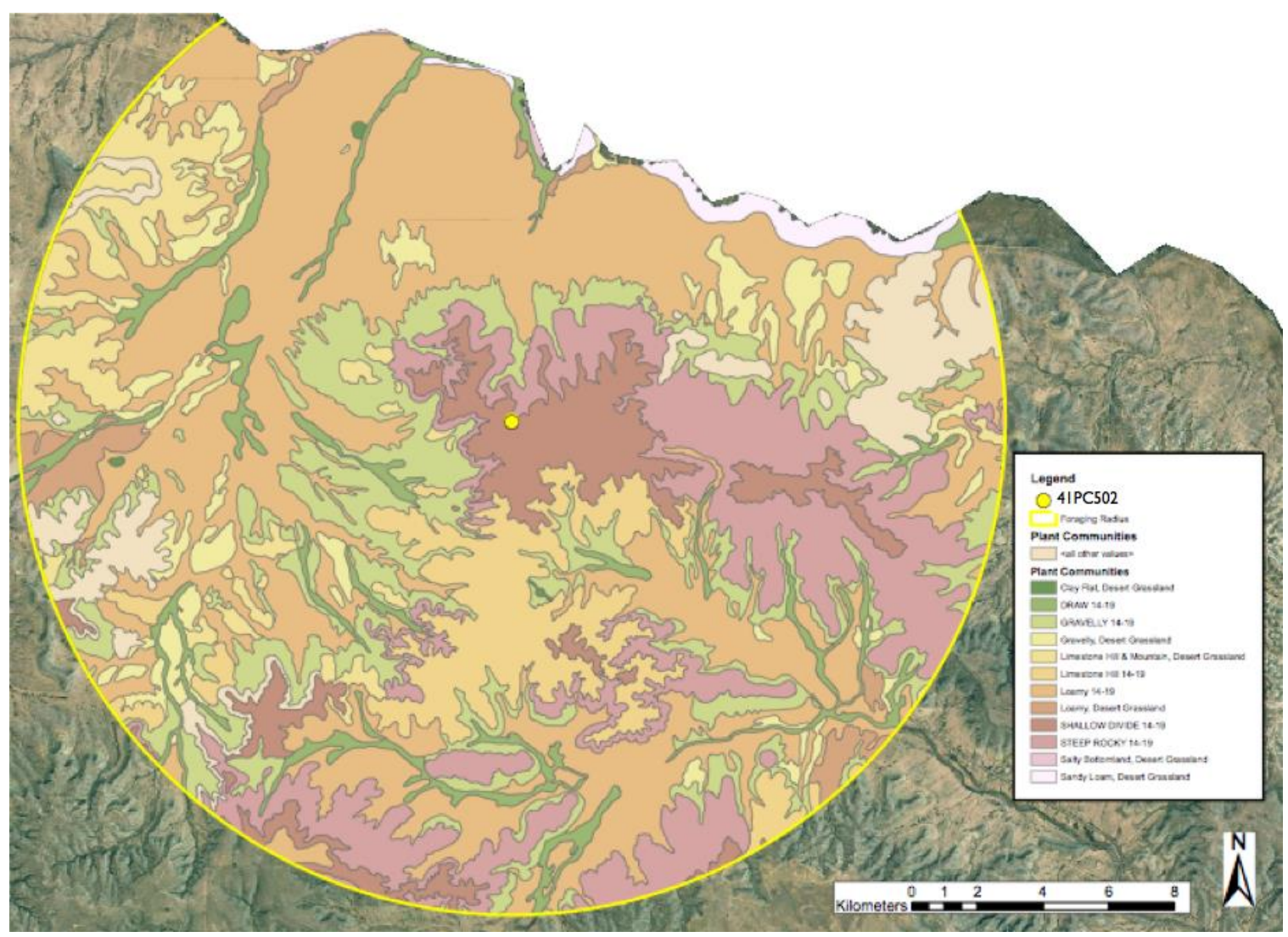

Figure 4. Example of ecological sites within the 41PC502 reconstructed foraging radius.

\section{Plant Taxa Diversity and Evenness}

To examine botanical diversity an index, Shannon's Diversity Index (SDI or $H^{\prime}$ ) (Figure 5), was added to the analysis as it is frequently used in landscape ecology to determine taxa richness (McGarigal et al. 2013; O'Neill et al. 1988). Here $R$ is the total number of species in the site catchment and $p_{i}$ the proportion of $S$ made up of the $i$ th species (Shannon and Weaver 1949). Results of this index are relative and the value increases as the number of unique taxa increases (McGarigal et al. 2013). A table was also generated to determine the number of unique taxa within each taxa, as well as<smiles>[R16]C1C=C(C#[R])CC1[R]</smiles>

Figure 5. Shannon's Diversity Index (SDI) (Shannon and Weaver 1949).

$$
E=\frac{H^{\prime}}{H_{\max }^{\prime}}
$$

Figure 6. Shannon's Evenness Index (SEI) (Shannon and Weaver 1949). the number of taxa which are encountered multiple times within the site catchment.

Another index, Shannon's Evenness Index (SEI) (Figure 6), was also used as this identifies how evenly species are dispersed in a given landscape (O'Neill et al. 1988). For this, the SDI $\left(H^{\prime}\right)$ is divided by the natural $\log$ of the total number of species on the landscape, $H_{\text {max }}^{\prime}$ (Shannon and Weaver 1949). With this index the closer the result (E) is to 1 the more evenly distributed species are on the landscape (McGarigal et al. 2013). 


\section{Comparative Analysis}

To determine available plant species a process had to be developed to compile this data because the species composition for the ecological sites/plant communities are not available from the Web Soil Survey county level downloads. Identifying which ecological sites are present within the reconstructed foraging catchment was determined by copying the relevant attribute data from the ecological site name-foraging radii spatial union. For determining plant taxon composition the ESD System for Rangeland and Forestland Data was accessed and the species copied and pasted into an Excel spreadsheet. To double check the ESD System for Rangeland and Forestland Data, a series of "Area of Interest" was generated in a Web Soil Survey session approximating the reconstructed foraging radii. Species composition missing from the ESD System for Rangeland and Forestland Data was then incorporated into the plant community spreadsheets. When taxa were encountered in the archeological record but not the current ecological data Powell $(1994,1998)$ and the USDA PLANTS Database (USDA-NRCS 2013) were examined to determine if the particular taxa could be present within the site catchments.

In order to compare the sizeable amount of botanical data, a table was developed that compared the prehistoric diet from each archeological site to the wild plant foods utilized by the Historic Mescalero Apache available within the site catchments. The reason for compiling information in this manner was to determine if prehistoric foragers were utilizing the same botanical species in the plant communities surrounding these archeological sites as the Mescalero Apache might have.

\section{RESULTS}

Results of the comparative analysis portion of the study identify a few unique observations as well as some complications in the use of the USDA-NRCS historic climax plant community data. Before an examination of the archeological-ethnohistoric comparisons, the missing plant species data from the ecological proxy must be addressed.

Two major hurdles encountered in the comparative analysis was the presence of areas with no defined ecological site within the site catchments and the existence of defined ecological sites with no available plant species composition data. The occurrence of these phenomena is likely due to a lack of reporting from the USDA-NRCS, BLM, and USDA-Forest Service, which is unsurprising given the large amount of work involved and that the ESD System was only recently initiated (USDA-NRCS 2007). Analytical implications for this primarily relate to not knowing the full vegetative suite within the ecological sites. However as Table 1 indicates, the SDI values are not very high $(>6)$, which is indicative of the fact that the landscapes are mildly heterogenous at the site catchment scale. The most hypothetically important ecological sites (i.e., riparian corridors) are missing plant species data. In the near future, this deficit will be righted as the USDA-NRCS, BLM, and USDA-Forest Service continue their efforts in reporting; at this time no attempt was made to account for this missing data.

Table 1 identifies the percentage of site catchment areas that have unknown ecological sites, known ecological sites with no historic climax community plant taxa data, and known ecological sites 
with historic climax community plant taxa data. In the future it is expected that this missing data will gradually be included. The two sites from Presidio County (Arroyo de la Presa site and Tres Metates Rockshelter) are the most reliable in terms of known data for the total site catchment areas.

Table 1. Known vs. unknown ecological site and plant taxa data.

\begin{tabular}{lllllllll}
\hline & $\begin{array}{l}\text { 41CU8 } \\
\mathbf{n}\end{array}$ & \% area & $\begin{array}{l}\text { 41PC502 } \\
\mathbf{n}\end{array}$ & \% area & $\begin{array}{l}\text { 41PS800 } \\
\mathbf{n}\end{array}$ & \% area & $\begin{array}{l}\text { 41PS915 } \\
\mathbf{n}\end{array}$ & \% area \\
\hline Unknown ESD & NA & 0.00 & NA & 5.3 & NA & 14.9 & NA & 21.1 \\
& 2 & 50.7 & 5 & 42.0 & 1 & 0.1 & 4 & 2.0 \\
$\begin{array}{l}\text { ESD-Known, } \\
\text { Plant Taxa-Unknown }\end{array}$ & & & & & & & & \\
$\begin{array}{l}\text { ESD-Known, } \\
\begin{array}{l}\text { Plant Taxa-Known } \\
\text { Total Number of }\end{array}\end{array}$ & 8 & 49.3 & 12 & 52.8 & 9 & 85.0 & 16 & 76.9 \\
Known Taxa & 97 & & 109 & & 135 & & 174 & \\
\hline
\end{tabular}

In relation to ecological information, Table 2 presents data regarding the total number of plant taxa, their frequency and uniqueness, and results of the SDI and SEI. The SDI demonstrates that the site catchment for Tres Metates Rockshelter (41PS915) has the most variation (SDI $=5.65)$ between the number of taxa while Granado Cave (41CU8) has the least variation (SDI $=4.43)$. In terms of the relative evenness of taxa, the SEI shows that the catchment of the Arroyo de la Presa (41PS800) site are dominated by fewer plant taxa $(\mathrm{SEI}=0.83)$ than the three other site catchments. However, Tres Metates Rockshelter has the least evenly distributed number of taxa $($ SEI $=0.91)$. This combined information demonstrates that for the Tres Metates Rockshelter catchment area there are a higher amount of botanical taxa dominating the landscape with a high amount of variation compared to the other three site catchment areas. It should be noted that none of the site catchments have complete ecological data and these values will potentially change in the future.

Table 2. Plant taxa distribution across site catchments with SDI and SEI values.

\begin{tabular}{lllll}
\hline \# of ESDs with & \multicolumn{4}{c}{ Number of Taxa Shared } \\
Shared Plant Taxa & 41 CU8 & 41 PC502 & 41PS800 & 41PS915 \\
\hline 1 & 57 & 62 & 75 & 82 \\
2 & 18 & 19 & 16 & 33 \\
3 & 17 & 12 & 19 & 10 \\
4 & 3 & 13 & 6 & 10 \\
5 & 2 & 4 & 5 & 14 \\
6 & 0 & 0 & 9 & 4 \\
7 & - & - & 2 & 5 \\
8 & - & - & 2 & 5 \\
9 & - & - & - & 1 \\
10 & - & - & - & 2 \\
11 & - & - & - & 1 \\
12 & - & & & \\
& & 4.5 & 4.72 & 5.65 \\
Shannon's Diversity Index & 4.43 & 0.84 & 0.83 & 0.91 \\
Shannon's Evenness Index & 0.86 & & & \\
\hline
\end{tabular}


Granado Cave (41CU8) had eight ecological sites but two do not currently have described plant species composition data. Unfortunately, these two ecological sites account for 50.7 percent of the site catchment area. However, for the six plant communities which do have known compositions, there are 97 plant taxa available (see Table 1). Of the plant species 14 (14.4 percent) would have been used by the Mescalero Apache as food resources but only seven are encountered archeologically (Table 3). One taxa is present in the archeo-dietary record, grape (Vitis sp.), but not in the ecological data. According to Castetter and Opler (1936), Arizona grape (Vitis arizonica) was consumed by the Mescalero Apache in the summer and fall and thus is not a dietary outlier. Powell (1998:256) concluded that Arizona grape is present in Culberson County, Texas, where Granado Cave is located. However, Arizona grape requires access to large amounts of water for growth and, despite being in an arid area, there are two riparian zone ecological sites (Bottomland [R042XC017NM] and Draw, Desert Grassland [R042XC242TX]), within the site catchment area but neither have historic climax plant community botanical taxa data. The presence of these riparian locales and the presence of the taxa in recent prehistoric archeological deposits suggests that grape plants are a component of the incomplete plant taxa dataset. In addition to this, the coprolite study from Hamilton (2001) demonstrated that grass (Poaceae) pollen is present in a significant portion of the coprolites. Unfortunately non-cultivated members of the family Poaceae cannot be identified beyond the family level with pollen (Bryant 2006), so which of the three taxa used by the Mescalero Apache and present in the site catchment (muhly grass [Muhlenbergia spp.], vine mesquite [Panicum obtusum], and sand dropseed [Sporobolus cryptandrus]) cannot be determined; consequently, they must be treated as one taxonomic unit in the analysis.

\section{Table 3. Ethnographically used and archeologically encountered plant taxa utilized in diet from Granado Cave.}

\begin{tabular}{lllll}
\hline Common Name & Taxon & $\begin{array}{l}\text { Mescalero } \\
\text { Apache }\end{array}$ & $\begin{array}{l}\text { Prehistoric } \\
\text { Diet }\end{array}$ & $\begin{array}{l}\text { Present in } \\
\text { ESD Data }\end{array}$ \\
\hline Agave & Agave sp. & $\mathrm{X}$ & $\mathrm{X}$ & $\mathrm{X}$ \\
lambsquarters & Chenopodium album & $\mathrm{X}$ & & $\mathrm{X}$ \\
smooth sotol & Dasylirion leiophyllum & $\mathrm{X}$ & & $\mathrm{X}$ \\
common sumflower & Helianthus annuus & $\mathrm{X}$ & $\mathrm{X}$ & $\mathrm{X}$ \\
algerita & Mahonia trifoliolata & $\mathrm{X}$ & & $\mathrm{X}$ \\
grass & POACEAE & $\mathrm{X}$ & $\mathrm{X}$ & $\mathrm{X}$ \\
Texas Sacahuista & Nolina texana & $\mathrm{X}$ & & $\mathrm{X}$ \\
prickly pear & Opuntia spp. & $\mathrm{X}$ & $\mathrm{X}$ & $\mathrm{X}$ \\
Western honey mesquite & Prosopis glandulosa & $\mathrm{X}$ & & $\mathrm{X}$ \\
grape & Vitis sp. & $\mathrm{X}$ & $\mathrm{X}$ & $\mathrm{X}$ \\
littleleaf sumac & Rhus microphylla & $\mathrm{X}$ & & $\mathrm{X}$ \\
yucca & Yucca & $\mathrm{X}$ & $\mathrm{X}$ & $\mathrm{X}$ \\
\hline
\end{tabular}

41PC502 had 12 ecological sites with only seven currently having species composition available.

The seven ecological sites with known plant taxa account for 52.8 percent of the site catchment area and they have 109 botanical taxa present (see Table 1). Fourteen (12.8 percent) of these taxa would have been used as food by the Mescalero Apache but only four are archeologically represented. Two additional taxa (lambsquarters/amaranth [Cheno-Ams] and purslane [Portulaca sp.]) are encountered in the archeological record and are known to have been eaten by the Mescalero Apache (Castetter and Basehart 1936) but are currently absent in the ecological data (Table 4). It should be noted that the 
taxonomic unit of Cheno-Ams consists of members of the family Chenopodiaceae and the genus Amaranthus in the family Amaranthaceae, but are difficult to separately discern in many archeological contexts (Dering 2004). The absence of Cheno-Ams and purslane in the ecological data is most likely due to the incomplete ecological proxy. However, the USDA PLANTS Database indicates these are ubiquitous across the Eastern Trans-Pecos (USDA-NRCS 2013) and are likely to contribute to the taxa composition of the missing ecological site data.

\section{Table 4. Ethnographically used and archeologically encountered plant taxa utilized in diet from 41PC502.}

\begin{tabular}{lllll}
\hline Common Name & Taxon & $\begin{array}{l}\text { Mescalero } \\
\text { Apache }\end{array}$ & $\begin{array}{l}\text { Prehistoric } \\
\text { Diet }\end{array}$ & $\begin{array}{l}\text { Present in } \\
\text { ESD Data }\end{array}$ \\
\hline Agave & Agave sp. & $\mathrm{X}$ & $\mathrm{X}$ & $\mathrm{X}$ \\
four-wing saltbush & Atriplex canescens & $\mathrm{X}$ & $\mathrm{X}$ ? & $\mathrm{X}$ \\
lambsquarters/amaranth & CHENO-Ams & $\mathrm{X}$ & $\mathrm{X}$ \\
sotol & Dasylirion sp. & $\mathrm{X}$ & & $\mathrm{X}$ \\
cruzilla & Forestiera pubescens & $\mathrm{X}$ & & $\mathrm{X}$ \\
Indian rushpea & Hoffmannseggia glauca & $\mathrm{X}$ & $\mathrm{X}$ \\
algerita & Mahonia trifoliolata & $\mathrm{X}$ & & $\mathrm{X}$ \\
muhly grass & Muhlenbergia spp. & $\mathrm{X}$ & & $\mathrm{X}$ \\
Texas sacahuista & Nolina texana & $\mathrm{X}$ & $\mathrm{X}$ & $\mathrm{X}$ \\
prickly pear & Opuntia spp. & $\mathrm{X}$ & $\mathrm{X}$ & $\mathrm{X}$ \\
vine mesquite & Panicum obtusum & $\mathrm{X}$ & & $\mathrm{X}$ \\
hogweed & Portulaca sp. & $\mathrm{X}$ & $\mathrm{X}$ & $\mathrm{X}$ \\
Western honey mesquite & Prosopis glandulosa & $\mathrm{X}$ & & $\mathrm{X}$ \\
littleleaf sumac & Rhus microphylla & $\mathrm{X}$ & & \\
sand dropseed & Sporobolus cryptandrus & $\mathrm{X}$ & $\mathrm{X}$ & \\
yucca & Yucca spp. & & & \\
\hline
\end{tabular}

$X$ ?=taxa questionably included as dietarily important/

The reconstructed foraging radius for the Arroyo de la Presa site (41PS800) had a total of nine ecological sites, although only eight currently have plant species composition data. These eight ecological sites account for 84.9 percent of the site catchment area. Within the reconstructed foraging radius there are a total of 135 plant taxa currently known (see Table 1). Thirteen (9.6 percent) of these are known to have been consumed by the Mescalero Apache, but only four are found in archeological samples (Table 5). As at 41PC502, Cheno-Ams are present in the samples and were consumed historically by the Mescalero Apache (Castetter and Basehart 1936). Cheno-Ams are not currently in the ESD System data but most likely are present in the biota as mentioned above. The fruits of one taxa, saltbush (Atriplex spp.), were encountered in the archeological record but were not apparently used by the Mescalero Apache. The presence of these seeds may be due to the use of saltbush as fuel (see below).

Tres Metates Rockshelter (41PS915) has the most ecological variability $(\mathrm{SDI}=5.65, \mathrm{SEI}=0.91)$ within this reconstructed foraging radius compared to the other three sites. Sixteen ecological sites are present in the site catchment area while four have yet to be described. Those presently having plant taxa composition data available account for 76.9 percent of the site catchment area. Of the 12 plant communities with available plant taxa data, 174 different taxa are present (see Table 1). Nineteen of these taxa have recorded dietary use among the Mescalero Apache and 15 are encountered archeologically (Table 6). Of those recovered in the archeological record, four have no known food 
use among the Mescalero Apache (Castetter and Opler 1936; Basehart 1960). These include saltbush, bristlegrass (Setaria ssp.), buffalo gourd (Cucurbita foetidissima), paspalum grass (Paspalum spp.), and plantain (Plantago spp.). Of these four only buffalo gourd is not present in the current ESD System data.

Table 5. Ethnographically used and archeologically encountered plant taxa utilized in diet from the Arroyo de la Presa site.

\begin{tabular}{|c|c|c|c|c|}
\hline Common Name & Taxon & $\begin{array}{l}\text { Mescalero } \\
\text { Apache }\end{array}$ & $\begin{array}{l}\text { Prehistoric } \\
\text { Diet }\end{array}$ & $\begin{array}{l}\text { Present in } \\
\text { ESD Data }\end{array}$ \\
\hline Agave & Agave sp. & $x$ & $\mathrm{X}$ & $\mathrm{X}$ \\
\hline four-wing saltbush & Atriplex canescens & & $X ?$ & $x$ \\
\hline lambsquarters/amaranth & CHENO-Ams & $\mathrm{X}$ & $X$ & \\
\hline sotol & Dasylirion sp. & $\mathrm{X}$ & & $\mathrm{X}$ \\
\hline cruzilla & Forestiera pubescens & $\mathrm{X}$ & & $X$ \\
\hline muhly grass & Muhlenbergia spp. & $\mathrm{X}$ & & $x$ \\
\hline Texas sacahuista & Nolina texana & $\mathrm{X}$ & & $x$ \\
\hline prickly pear & Opuntia spp. & $x$ & $x$ & $x$ \\
\hline vine mesquite & Panicum obtusum & $\mathrm{X}$ & & $x$ \\
\hline hogweed & Portulaca sp. & $\mathrm{x}$ & & $x$ \\
\hline Western honey mesquite & Prosopis glandulosa & $x$ & $X$ & $x$ \\
\hline littleleaf sumac & Rhus microphylla & $\mathrm{X}$ & & $x$ \\
\hline sand dropseed & Sporobolus cryptandrus & $\mathrm{X}$ & & $x$ \\
\hline yucca & Yucca spp. & $\mathrm{X}$ & & $\mathrm{X}$ \\
\hline
\end{tabular}

$\mathrm{X}$ ?=taxa questionably included as dietarily important/

Table 6. Available, ethnographically used, and archeologically encountered plant taxa utilized in diet from Tres Metates Rockshelter.

\begin{tabular}{lllll}
\hline Common Name & Taxon & $\begin{array}{l}\text { Mescalero } \\
\text { Apache }\end{array}$ & $\begin{array}{l}\text { Prehistoric } \\
\text { Diet }\end{array}$ & $\begin{array}{l}\text { Present in } \\
\text { ESD Data }\end{array}$ \\
\hline Agave & Agave sp. & $\mathrm{X}$ & $\mathrm{X}$ & $\mathrm{X}$ \\
onion & Allium spp. & $\mathrm{X}$ & $\mathrm{X}$ & $\mathrm{X}$ \\
amaranth & Amaranthus spp. & $\mathrm{X}$ & $\mathrm{X}$ & $\mathrm{X}$ \\
four-wing saltbush & Atriplex canescens & & $\mathrm{X}$ ? & \\
buffalo gourd & Cucurbita foetidissima & & $\mathrm{X}$ & $\mathrm{X}$ \\
tree cholla & Cylindropuntia imbricata & $\mathrm{X}$ & $\mathrm{X}$ & $\mathrm{X}$ \\
sotol & Dasylirion sp. & $\mathrm{X}$ & $\mathrm{X}$ & $\mathrm{X}$ \\
rushpea & Hoffmannseggia sp. & $\mathrm{X}$ & & $\mathrm{X}$ \\
muhly grass & Muhlenbergia spp. & $\mathrm{X}$ & & $\mathrm{X}$ \\
sacahuista & Nolina texana & $\mathrm{X}$ & & $\mathrm{X}$ \\
prickly pear & Opuntia spp. & $\mathrm{X}$ & $\mathrm{X}$ & $\mathrm{X}$ \\
vine mesquite & Panicum obtusum & $\mathrm{X}$ & & $\mathrm{X}$ \\
paspalum grass & Paspalum sp. & & $\mathrm{X}$ ? \\
pinon pine & Pinus cembroides & $\mathrm{X}$ & & $\mathrm{X}$ \\
plantain & Plantago sp. & $\mathrm{X}$ & $\mathrm{X}$ & $\mathrm{X}$ \\
purslane & Portulaca spp. & $\mathrm{X}$ & $\mathrm{X}$ & $\mathrm{X}$ \\
Western honey mesquite & Prosopis glandulosa & $\mathrm{X}$ & $\mathrm{X}$ & $\mathrm{X}$ \\
screwbean mesquite & Prosopis pubescens & $\mathrm{X}$ & $\mathrm{X}$ & $\mathrm{X}$ \\
oak & Quercus spp. & $\mathrm{X}$ & $\mathrm{X}$ & $\mathrm{X}$ \\
fragrant sumac & Rhus trilobata & $\mathrm{X}$ & $\mathrm{X}$ & $\mathrm{X}$ \\
sand dropseed & Sporobolus cryptandrus & $\mathrm{X}$ & $\mathrm{X}$ ? \\
bristlegrass & Setaria spp. & $\mathrm{X}$ & $\mathrm{X}$ & $\mathrm{X}$ \\
yucca & Yucca spp. & &
\end{tabular}

$X$ ?=taxa questionably included as dietarily important/ 


\section{DISCUSSION}

Results of this study indicate there are four overlying patterns concerning Late Prehistoric Era native plant diet among hunter-gatherers and forager-farmers in the Eastern Trans-Pecos archeological region. These patterns can be grouped into three primary observations: similarity between the historic and prehistoric groups; preservation induced bias; and problems with the ecological proxy.

As demonstrated in Table 7, there is a wide variation in prehistoric subsistence use of plant taxa compared to the Mescalero Apache. However, the prehistoric samples are dominated by four taxa: prickly pear (Opuntia spp.), mesquite (Proposis spp.), yucca (Yucca spp.), and agave (Agave sp.) (see Tables 3-6). This furthers the dietary similarity between the historic and prehistoric groups as these four taxa are also the dominant botanical dietary species for the Mescalero Apache (Basehart 1960).

Table 7. Number of plant taxa available, used by the Mescalero Apache, and encountered in the archeological record.

\begin{tabular}{llll}
\hline Site & Total No. of Taxa & $\begin{array}{l}\text { Total No. of Taxa Used by } \\
\text { Mescalero Apache }\end{array}$ & $\begin{array}{l}\text { Total No. of Taxa Encountered in the } \\
\text { Archeological Record }\end{array}$ \\
\hline 41CU8 & 97 & 12 & 6 \\
41PC502 & 109 & 16 & 4 \\
41PS800 & 135 & 11 & 4 \\
41PS915 & 174 & 18 & 17 \\
\hline
\end{tabular}

Results of the comparative analysis indicate that there is not complete dietary overlap between the Mescalero Apache and Late Prehistoric groups that occupied the four sites, but the dietary plant species are quite similar. Any dissimilarity is caused by the presence of three confirmed dietary taxa based on the ethnographic record that are also present in archeological samples. Plantago seeds were encountered in the feature fill from 41PC502 and the seeds of one species, woolly plantain (Plantago patagonica), are known to have been consumed by three cultural groups (Moerman 2010). Because this taxa has no recorded use among Apachean groups it may never have been adopted by these immigrating peoples and would be indicative of dietary acculturation processes. The same can be said for buffalo gourd, which was used by four groups across the American Southwest and California as a food source, is present in the storage feature at Tres Metates Rockshelter, but was not used by the Mescalero Apache or any other Apachean group (Moerman 2010).

This analysis also questions the inclusion of two grass (Paspalum spp. and Setaria spp.) and one shrub taxa (Atriplex spp.) as dietarily important within the Eastern Trans-Pecos archeological region. Paspalum grass seeds were present at Tres Metates Rockshelter but were not used by the Mescalero Apache. In fact, only one species of paspalum grass, thin paspalum (Paspalum setaceum), is known to have had an ethnographic dietary use according to Moerman (2010) but this species is not found in Trans-Pecos Texas (Powell 1994; Vestal and Schultes 1939). However, four species of paspalum grass are known to occur in the Trans-Pecos Region (Powell 1994). Bristlegrass seeds and florets are also present at Tres Metates Rockshelter, but have no known ethnographic use (Moerman 2010). Because of this, and the fact that Seebach (2007) indicates grass was incorporated into the lining of the storage pit, it is likely that the bristlegrass and paspalum grass seeds are not reflective of diet but were incorporated instead because of these of these grasses in feature construction. Finally, one other plant 
taxa, saltbush (Atriplex spp.), may not have been used as a food resource in the region but was included in features for non-dietary reasons.

Within the Trans-Pecos region there are four native taxa of saltbush: tubercled saltbush (Atriplex acanthocarpa), obovate leaf saltbush (Atriplex obovata), spiny saltbush (Atriplex confertifolia), and fourwing saltbush (Atriplex canescens) (Powell 1998). Three of these (obovateleaf saltbush, spiny saltbush, and four-wing saltbush) are used primarily as flavorings for a variety of dishes or as greens (Moerman 2010). Of those present in the Trans-Pecos, spiny saltbush and four-wing saltbush are the only two whose seeds have been ethnographically documented as food sources (Chamberlin 1911; Moerman 2010). Obovate leaf saltbush was used as a spice and for greens (Colton 1974; Whiting 1939), while tubercled saltbush has no known dietary use (Moerman 2010). Spiny saltbush only occurs in the very far western portion of the region and obovate leaf saltbush is present only in the southwestern portion of the study area, making the identification of the saltbush seeds at 41PC502 as most likely four-wing saltbush, which is found throughout the Trans-Pecos (Powell 1998). Because the seeds of four-wing saltbush seeds are rarely consumed but used as a spice among the Ramah Navajo (Vestal 1952), and saltbush was a fuel or kindling source at 41PC502 (Antiquities Planning and Consulting 2002), it is more likely that the seeds reflect their incorporation in fuel/kindling or use as a spice used in cooking rather than as a food source.

Four-wing saltbush seeds are also present at Tres Metates Rockshelter in a plant-lined storage pit (Seebach 2007). However, as stated above, this taxon is a rarely used food source. Seebach (2007:26) did indicate that wooden sticks were included in the storage pit's structure but identification of these materials was not presented in the report. Therefore, if any of these wooden elements are from fourwing saltbush, which is present in the site catchment, there is a high likelihood that these seeds were originally from the structural elements rather than a stored food source.

Of the taxa which are not observed in the archeological samples, the vast majority are taxa utilized for fruit and starchy foods. While it is possible to recover starch residue from archeological contexts (e.g., Messner 2011; Perry and Quigg 2011), and I have attempted to obtain sources of this proxy, none have been published for the Late Prehistoric Era in the Eastern Trans-Pecos archeological region. Fruit and starchy foodstuffs are also the least likely to be preserved in the archeological record (Pearsall 2010). Unfortunately, the fruit foods were key to the warm season diet among the Mescalero Apache (Basehart 1960; Castetter and Opler 1936), and it can only be assumed that these were vital to Late Prehistoric peoples as well.

An overarching issue with this analysis are the incomplete ESD System historic climax plant community descriptions. At this time, 13 of the 34 plant communities within the reconstructed foraging radii are missing. This is most likely the reason some of the plant taxa found in the archeological samples are missing in the ecological proxy. However, with continued completion of these plant community descriptions, specifically those in the vastly important riparian areas, an even better understanding of prehistorically available native plant species can be developed. Regardless, this study demonstrates that the ESD System can be used for archeological landscape use studies as the majority of botanical taxa (80.2 percent) documented in the archeological samples are present in current plant community descriptions. Additionally, despite the incomplete ESD System for the study 
area, the results indicate that many more plant taxa would have been available to prehistoric huntergatherers than the archeological record indicates. However, future studies focusing on microbotanical remains, specifically starch grains and phytoliths, are needed to confirm this.

Finally, findings of this study support a hypothesis proposed by Seebach (2007) that La Junta District forager-farmers traveled away from villages to procure foodstuffs. Seebach (2007:44-45) stated that individuals utilized Tres Metates Rockshelter as a location for procuring and storing locally available foods. The $15 \mathrm{~km}$ reconstructed foraging radius for this archeological site has the most ecological variability of all four radii in both number of known botanical taxa, number of ecological sites, and heterogeneity of taxa across the site catchment (see Table 2). This variability is a potential reason why forager-farmers utilized this archeological site in addition to the food storage and preservation capabilities of the rockshelter.

\section{CONCLUSIONS}

The native botanical component of diet between the Historic Mescalero Apache and the Late Prehistoric inhabitants of the eastern Trans-Pecos is quite similar when comparing recovered plant remains to ethnographic information. A cursory examination of these data indicate that the Late Prehistoric native plant diet was much more restricted than the Mescalero Apache wild land botanical diet. However, plant parts with low preservation values (i.e., fruits, leaves, flowers, and flower stalks) account for 57 percent of plant species utilized as wild land foods in this group (Castetter and Opler 1936). Despite being of vital importance, these plant parts are highly unlikely to be encountered in the archeological record. By utilizing proxies solely derived from the archeological record, paleoethnobotanists would be greatly amiss in assessing hunter-gatherer paleonutrition. Results of this study also indicate native plant diet for Late Prehistoric era peoples was probably much more diverse than the archeological record indicates and that some form of dietary acculturation occurred during the absorption of incipient groups by the Mescalero Apache. However, four staples (prickly pear, mesquite, yucca, and agave) dominated native botanical foods for these Late Prehistoric Era peoples.

The utility of ESD historic climax plant community descriptions is also demonstrated to be of value in archeological analysis despite their incomplete status. Unfortunately, users of this spatial data system can only wait until the involved entities complete their reporting, but in the interim a similar analysis should be conducted in areas where the ESD System has been completed to further test the use of the system. Regardless, by utilizing a proxy that is more descriptive and more frequently used than others (e.g., Texas Parks and Wildlife Department Vegetation Types or U.S. Environmental Protection Agency Ecoregions as suggested by Arnn [2012]) for current landscape management, it is possible for multiple scientific fields to converge and expand the utility and accuracy of these plant community descriptions.

\section{ACKNOWLEDGEMENTS}

I wish to thank my Master's Degree Committee (Vaughn M. Bryant, Ph.D.; Suzanne Eckert, Ph.D.; and Wayne Hamilton, M.S., M.B.A.) for their many helpful comments and critiques of the 
manuscript this article is based on. Other special thanks go to Dr. Zac Selden for recommending this journal as an avenue of publication, the Editor-in-Chief Timothy K. Perttula for editing, and the three anonymous reviewers for comments and feedback that helped strengthen this study. Finally, Dr. Alston Thoms, should be thanked as the semester research paper for his ANTH 620: The Prehistory of Texas course served as the beginning point for this undertaking.

\section{REFERENCES CITED}

Antiquities Planning and Consulting

2002 Sustainable Subsistence: Archeological Survey and Data Recovery at the Indian Wind Mesa Turbine Farm near Bakersfield in Northeast Pecos County, Texas. Kyle, Texas.

Arnn, J. W.

2012 Land of the Texas: Native American Identity and Interaction in Texas, A.D. 1300-1700. University of Texas Press, Austin.

Basehart, H. W.

1960 Mescalero Apache Subsistence Patterns and Socio-Political Organization: Section I. A Report of the Mescalero-Chiricahua Land Claims Project. Contract Research \#290-154. The University of New Mexico, Albuquerque.

Beisner, B. E., D. T. Haydon, and K. Cuddington

2003 Alternative stable states in ecology. Frontiers in Ecology and the Environment 1(7):376-382.

Bryant, V. M.

2006 Pollen Analysis of Archaeological Sediments from the Paradise Site: Appendix II. In The Paradise Site: A Middle Archaic Campsite on the O2 Ranch, Presidio County, Texas, by A. J. Ohl, pp. 149-170. Papers of the Trans-Pecos Archaeological Program, No. 2. Center for Big Bend Studies, Sul Ross State University, Alpine.

Castetter, E. F. and M. E. Opler

1936 Ethnobiological Studies in the American Southwest: The Ethnobiology of the Chiricahua and Mescalero Apache, A: The Use of Plants for Foods, Beverages and Narcotics. Bulletin 297. University of New Mexico, Albuquerque.

Chamberlin, R. V.

1911 The Ethnobotany of the Gosuite Indians of Utah. Memoirs of the American Anthropological Association 2(5):331-405.

Cloud, W. A.

2004 The Arroyo de la Presa Site: A Stratified Late Prehistoric Campsite Along the Rio Grande, Presidio County, Texas. Reports in Contract Archeology 9. Center for Big Bend Studies, Alpine, Texas and Texas Department of Transportation, Austin. 
Cloud, W. A. and J. C. Piehl

2008 The Millington Site: Archaeological and Human Osteological Investigations. Papers of the TransPecos Archaeological Program 4. Center for Big Bend Studies, Sul Ross State University, Alpine.

Collins, M. B.

2004 Archeology in Central Texas. In The Prehistory of Texas, edited by T. K. Perttula, pp. 101-127. Texas A\&M University Press, College Station.

Colton, H. S.

1974 Hopi History and Ethnobotany. In Hopi Indians, edited by D. A. Horr, pp. 279-373. Garland Publishing, New York.

Davis, O. K.

1989 The Regionalization of Climatic Change in Western North America. In Paleoclimatology and Paleometeorology: Modern and Past Patterns of Global Atmospheric Transport, edited by M. Leinen and M. Sarnthein, pp. 617-636. Kluwer Academic, Amsterdam.

Dering, J. P.

2004 Plant Remains from the Arroyo de la Presa Site (41PS800), Presidio County, Trans-Pecos Texas: Appendix III. In The Arroyo de la Presa Site: A Stratified Late Prehistoric Campsite Along the Rio Grande, Presidio County, Texas, by W. A. Cloud, pp. 201-210. Reports in Contract Archeology 9. Center for Big Bend Studies, Alpine, Texas, and Texas Department of Transportation, Austin.

Elias, S. A. and T. R. Van Devender

1992 Insect Fossil Evidence of Late Quaternary Environments in the Northern Chihuahuan Desert of Texas and New Mexico: Comparisons with the Paleobotanical Record. The Southwestern Naturalist 37(2):101-116.

Hamilton, D. L.

2001 Prehistory of the Rustler Hills, Granado Cave. University of Texas Press, Austin.

Hatch, S. L., K. N. Gandhi, and L. E. Brown

1990 Checklist of the Vascular Plants of Texas. Texas Agricultural Experiment Station, Texas A\&M University System, College Station.

Hickerson, N. P.

1994 Jumanos: Hunters and Traders of the South Plains. University of Texas Press, Austin.

Holling, C. S.

1973 Resilience and stability of ecological systems. Annual Review of Ecological Systems 4:1-24. 
Hoyt, C. A.

2000 Grassland to Desert: Holocene Vegetation and Climate Change in the Northern Chihuahuan Desert. Ph.D. dissertation, Department of Anthropology, The University of Texas at Austin.

Johnson, L.

1994 The Life and Times of Toyah-Culture Folk: The Buckhollow Encampment, Site 41KM16, Kimble County, Texas. Office of the State Archeologist, Report 38. Texas Department of Transportation and Texas Historical Commission, Austin.

Kelley, J. C.

1957 The Livermore Focus: A Clarification. El Palacio 64(1-2):44-52.

1986 Jumano and Patarabueye: Relations at La Junta de los Rios. Anthropological Papers 77. Museum of Anthropology, University of Michigan, Ann Arbor.

Kelley, J. C., T. N. Campbell, and D. L. Lehmer

1940 The Association of Archaeological Materials with Geological Deposits in the Big Bend Region of Texas. Sul Ross State Teachers College Bulletin 21(3):1-173.

Kelly, R. J.

1995 The Foraging Spectrum. Smithsonian Institution Press, Washington, D.C.

Kenmotsu, N. A.

1994 Helping Each Other Out: A Study of the Mutualistic Relations of Small Scale Foragers and Cultivators in the La Junta de los Rios Region. Ph.D. dissertation, Department of Anthropology, University of Texas at Austin.

2013 Pottery at La Junta: One View of Regional Interaction Along the Rio Grande. Bulletin of the Texas Archeological Society 84:5-29.

Kenmotsu, N. A. and J. W. Arnn

2012 The Toyah Phase and the Ethnohistorical Record: A Case for Population Aggregation. In The Toyah Phase of Central Texas: Late Prehistoric Economic and Social Processes, edited by N. A. Kenmotsu and D. K. Boyd, pp. 19-44. Texas A\&M University Press, College Station.

Kenmotsu, N. A. and M. F. Wade

2002 American Indian Tribal Affiliation Study, Phase I: Ethnohistoric Literature Review. Archeological Studies Program, Report No. 34. Texas Department of Transportation, Austin, and National Park Service, Amistad National Recreation Area, Del Rio.

Kim, M. J., S. J. Lee, Y. Ahn, P. Bowen, and H. Lee

2007 Dietary Acculturation and Diet Quality of Hypertensive Korean Americans. Journal of Advanced Nursing 58(5):436-445. 
Law, R. and R. D. Morton.

1993 Alternative permanent states of ecological communities. Ecology 74:1347-1361.

Mallouf, R. J.

1985 A Synthesis of Eastern Trans-Pecos Prehistory. Master's thesis, Department of Anthropology, The University of Texas at Austin.

1999 Comments on the Prehistory of Far Northeastern Chihuahua, the La Junta District and the Cielo Complex. Journal of Big Bend Studies 11:49-92.

2009 The John Z. and Exa Means Cache, New Discovery Yields Insights into Big Bend's Prehistoric Indians. La Vista de la Frontera 20:1-3.

2012 Some New and Revised Projectile Point Classifications for the Eastern Trans-Pecos and Big Bend Regions of Texas. La Tierra: Journal of the Southern Texas Archeological Association 39:5-22

2013 New and Revised Projectile Point Classifications for the Eastern Trans-Pecos and Big Bend Regions of Texas. In Archaeological Explorations of the Eastern Trans-Pecos and Big Bend: Collected Papers, Volume 1, edited by P. Dasch and R. J. Mallouf, pp. 191-214. Papers in the TransPecos Archaeological Program, No. 6. Center for Big Bend Studies, Sul Ross University, Alpine.

McGarigal, K., S. A. Cushman, and E. Ene

2013 FRAGSTATS Help Manual. In FRAGSTATS v4: Spatial Pattern Analysis Program for Categorical and Continuous Maps. Computer software program produced by the authors at the University of Massachusetts, Amherst.

Messner, T. C.

2011 Acorns and Bitter Roots: Starch Grain Research in the Prehistoric Eastern Woodlands. The University of Alabama Press, Tuscaloosa.

Miller, M. R. and N. A. Kenmotsu

2004 Prehistory of the Jornada Mogollon and Eastern Trans-Pecos Regions of West Texas. In The Prehistory of Texas, edited by T. K. Perttula, pp. 205-266. Texas A\&M University Press, College Station.

Moerman, D. E.

2010 Native American Food Plants: An Ethnobotanical Dictionary. Timber Press, Portland.

O’Neill, R.V., J. R. Krummel, R. H. Gardner, G. Sugihara, B. Jackson, D. L. DeAngelis, B. T. Milne, M. G. Turner, B. Zygmunt, S. W. Christensen, V. H. Dale, and R. L. Graham

1988 Indices of Landscape Pattern. Landscape Ecology 1(3):153-162.

Pearsall, D. M.

2010 Paleoethnobotany: A Handbook of Procedures. Second Edition. Left Coast Press, Walnut Creek. 
Perry, L. and J. M. Quigg

2011 Starch Remains and Stone Boiling in the Texas Panhandle Part 1: The Pipeline Site. Plains Anthropologist 56:95-107.

Perttula, T. K.

2004 An Introduction to Prehistoric Texas Archaeology. In The Prehistory of Texas, edited by T. K. Perttula, pp. 5-15. Texas A\&M University Press, College Station.

Poulos, H. M.

2007 Top down and bottom up influences on fire regimes, diversity, and vegetation patterns in the Chihuahuan Desert Borderlands. Ph.D. Dissertation, School of Forestry and Environmental Studies, Yale University, New Haven.

Powell, A. M.

1994 Grasses of the Trans-Pecos and Adjacent Areas. University of Texas Press, Austin.

1998 Trees and Shrubs of the Trans-Pecos and Adjacent Areas. University of Texas Press, Austin.

Pronatura Noreste, The Nature Conservancy, and World Wildlife Fund

2004 Ecoregional Conservation Assessment of the Chihuahuan Desert. Second Edition. PDF file retrieved from:

http://www.conservationgateway.org/ConservationPlanning/SettingPriorities/Ecoregional Reports/Pages/EastData.aspx.

Regev-Tobias, H., R. Reifen, R. Endevelt, O. Havkin, E. Cohen, G. Stern, and A. Stark

2012 Dietary Acculturation and Increasing Rates of Obesity in Ethiopian Woman Living in Israel. Nutrition 28(1):30-34.

Satia-Abouta, J.

2003 Dietary Acculturation: Definition, Process, Assessment, and Implications. International Journal of Human Ecology 4(1):71-86.

Seebach, J. D.

2007 Late Prehistory Along the Rimrock, Pinto Canyon Ranch. Papers of the Trans-Pecos Archaeological Program, Number 3. Center for Big Bend Studies, Sul Ross State University, Alpine.

Seymour, D. J.

2004 A Ranchería in the Gran Apachería: Evidence of Intercultural Interaction at the Cerro Rojo Site. Plains Anthropologist 49:153-192.

2012 Gateways for Athabascan Migration to the American Southwest. Plains Anthropologist 57(222):149-161. 
Shannon, C. E. and W. Weaver

1949 The Mathematical Theory of Communication. University of Illinois Press, Urbana.

Turner, E. S., T. R. Hester, and R. L. McReynolds

2011 The Stone Artifacts of Texas Indians. Taylor Trade Publishing, Lanham.

Turpin, S. A.

2004 The Lower Pecos River Region of Texas and Northern Mexico. In The Prehistory of Texas, edited by T. K. Perttula, pp. 266-283. Texas A\&M University Press, College Station.

USDA-NRCS

2007 Ecological Sites and Forage Suitability Groups. In National Range and Pasture Handbook. Grazing Lands Technology Institute, Fort Worth, Texas.

2012 About NRCS. http://www.nrcs.usda.gov/wps/portal/nrcs/main/national/about/. Accessed March 20, 2013.

2013 The PLANTS Database. http://plants.usda.gov. Accessed March 20, 2013

USDA-NRCS, U.S. Department of the Interior, and U.S. Forest Service

2013 Interagency Ecological Site Handbook for Rangelands. http://directives.sc.egov.usda.gov/OpenNonWebContent.aspx?content=33943.wba. Accessed June 24, 2013.

Van Devender, T. R.

1990 Late Quaternary Vegetation and Climate of the Chihuahuan Desert, United States and Mexico. In Packrat Middens: The Last 40,000 Years of Biotic Change, edited by J. L. Betancourt, T. R. Van Devender, and P. S. Martin, pp. 104-133. University of Arizona Press, Tucson.

Vesta, P. A. and R. E. Schultes

1939 The Economic Botany of the Kiowa Indians. Botanical Museum of Harvard University, Cambridge.

Warnock, B. J.

2010 A Brief History of Fire in the Trans-Pecos Region of Texas. In Proceedings: Trans-Pecos Prescribed Fire Symposium 2010, edited by K. A. Cearley, pp. 23-27. Texas AgriLife Extension Service, College Station.

Wells, P. V.

1966 Late Pleistocene Vegetation and Degree of Pluvial Climatic Change in the Chihuahuan Desert. Science 153: 970-975.

Whiting, A. F.

1939 Ethnobotany of the Hopi. Bulletin No. 15. Museum of Northern Arizona, Flagstaff. 
Wilcox, D. R.

1981 The Entry of the Athabaskan into the American Southwest: The Problem Today. In The Protohistoric Period in the American Southwest, A.D. 1450-1700, edited by D. R. Wilcox and W. B. Masse, pp. 213-256. Anthropological Research Papers No. 24. Arizona State University, Tempe. 